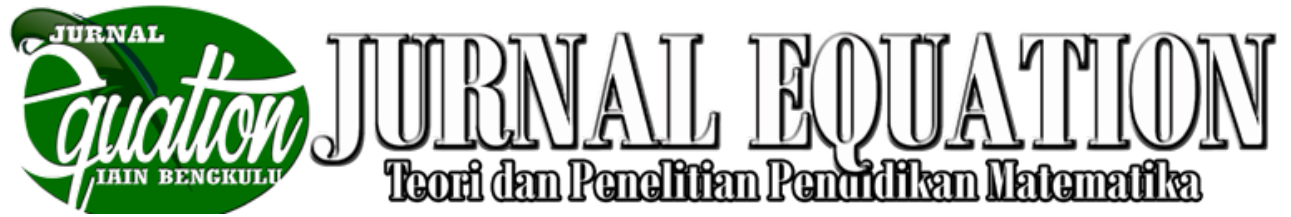

Volume 1 Nomor 2, September 2018, ISSN 2599-3291 (Cetak), ISSN 2614-3933 (Online)

\title{
Respon Mahasiswa Terhadap Pengembangan Nilai Karakter Setelah Mengimplementasikan Pembelajaran Matematika
}

\author{
Epran ${ }^{1)}$, Adelina Efriyanti²), Hanisah Tri Utami3) \\ 1) 2) 3)Fakultas Keguruan dan Ilmu Pendidikan, Universitas Bengkulu \\ 1)epranabdullah@gmail.com, 2)adelinaefriyanti2012@gmail.com, ${ }^{3)}$ Hanisahtri22@gmail.com
}

\begin{abstract}
ABSTRAK
Pendidikan sesungguhnya berawal dari kehidupan keluarga, kemudian secara efektif, efisien, dan metodik serta sistemik dilanjutkan di sekolahan dan pada akhirnya dilanjutkan dalam kehidupan sosial di masyarakat. Pendidikan karakter mejadi populer di negara Indonesia akhir-akhir ini, terutama setelah reformasi. Salahsatunya adalah pendidikan karakter melalui pembelajaran matematika. Secara umum, sikap matematika ditunjukkan oleh indikator adanya rasa senang dan ikhlas untuk mempelajari matematika, sikap yang mendukung untuk mempelajari matematika, pengetahuan yang cukup untuk mempelajari matematika, rasa ingin tahu, kemamuan untuk bertanya, untuk memperoleh keterampilan dan pengalaman matematika. Perguruan tinggi, khususnya lembaga pendidikan tenaga kependidikan yang bertugas menyiapkan guru-guru, tentunya mempunyai kewajiban moral untuk membantu guru dalam masalah yang dijumpai di sekolah, tak terkecuali membantu guru dalam menyiapkan pembelajaran yang menunjang ke pendidikan karakter, termasuk masalah yang dihadapi oleh guru matematika. Tulisan ini akan memberikan gambaran bagaimana pendidikan karakter dapat dikembangkan dalam pembelajaran matematika.
\end{abstract}

Kata Kunci : pendidikan karakter, pembelajaran matematika

\section{PENDAHULUAN}

Pendidikan sesungguhnya berawal dari kehidupan keluarga, kemudian secara efektif, efisien, dan metodik serta sistemik dilanjutkan di sekolahan dan pada akhirnya dilanjutkan dalam kehidupan sosial di masyarakat. Pendidikan formal bukan hanya ditekankan pada ketersediaan sarana sekolah saja, tetapi diimbangi dengan sarana pengajaran misalnya perkembangan teknologi saat ini.

Pendidikan karakter mejadi populer di negara Indonesia akhir-akhir ini, terutama setelah reformasi. Dalam salah satu harian nasional (Kompas, 3 Mei 2011) disebutkan pada topik pendidikan kararkter, bahwa pendidikan karakter dan penanaman nilai-nilai nasionalisme di sekolah tidak berjalan efektif karena siswa tidak menemukan sosok teladan. Pengalaman yang mereka lihat kurang mencerminkan pendidikan karakter, bahkan malah berlawanan. Mereka hanya mendengar karakter baik, kejujuran, pengorbanan kepada sesama, patriotisme, jarang menemukan hal itu dalam kehidupan sehari-hari. Ada yang menyebut hal ini, disebabkan antara lain karena Pendidikan Pancasila dihapus (Kompas, 6 mei 2011). Oleh karena itu ada yang mengusulkan agar ajaran Pancasila direvitalisasi (Kompas, 7 Mei 2011). Mensikapi hal tersebut, kementerian pendidikan nasional republik Indonesia telah 


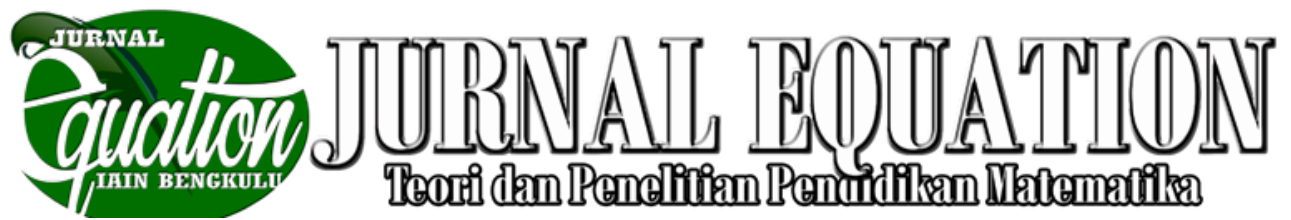

Volume 1 Nomor 2, September 2018, ISSN 2599-3291 (Cetak), ISSN 2614-3933 (Online)

mencanangkan pengembangan budaya dan karakter bangsa, yang lebih populer dengan sebutan pendidikan berkarakter. Pendidikan karakter sejatinya sudah lama terkandung secara implisit dalam pendidikan kita sejak jaman dahulu. Namun akhir-akhir ini semakin perlu dan memperoleh perhatian yang besar, mengingat nilai-nilai, moral, estetika, dan karakter semakin kurang atau bahkan jarang dijumpai. Bagi guru hal ini, mungkin menjadi tantangan baru, selain pencapaian tujuantujuan pembelajaran yang bersifat kognitif yang sampai sekarang masih menjadi tugas yang cukup berat, terutama bagi guru-guru mata pelajaran umum, seperti matematika.

Kurikulum (2004) menyatakan bahwa "Matematika adalah studi tentang bahanbahan yang memiliki objek abstrak dan dibangun melalui proses penalaran deduktif, bahwa konsep kebenaran diperoleh sebagai konsekuensi logis dari kebenaran diterima sebelumnya bahwa hubungan antara konsep matematika dalam yang sangat kuat dan jelas".

Perguruan tinggi, khususnya lembaga pendidikan tenaga kependidikan yang bertugas menyiapkan guru-guru, tentunya mempunyai kewajiban moral untuk membantu guru dalam masalah yang dijumpai di sekolah, tak terkecuali membantu guru dalam menyiapkan pembelajaran yang menunjang ke pendidikan karakter, termasuk masalah yang dihadapi oleh guru matematika. Tulisan ini akan memberikan gambaran bagaimana pendidikan karakter dapat dikembangkan dalam pembelajaran matematika. Oleh karena itu penulis akan mengangkat sebuah judul "Respon Mahasiswa Terhadap Pengembangan Nilai Karakter Setelah Mengimplementasikan Pembelajaran Matematika". Adapun tujuan dari penulisan ini yaitu untuk mengetahui proses pengimplementasian nilai karakter dalam pembelajaran matematika.

\section{Mahasiswa}

Mahasiswa adalah seseorang yang sedang dalam proses menimba ilmu ataupun belajar dan terdaftar sedang menjalani pendidikan pada salah satu bentuk perguruan tinggi yang terdiri dari akademik, politeknik, sekolah tinggi, institut dan universitas (Hartaji, 2012: 5). Dalam Kamus Bahasa Indonesia (KBI), mahasiswa didefinisikan sebagai orang yang belajar di Perguruan Tinggi (Kamus Bahasa Indonesia Online, kbbi.web.id) Menurut Siswoyo (2007: 121) mahasiswa dapat didefinisikan sebagai individu yang sedang menuntut ilmu ditingkat perguruan tinggi, baik negeri maupun swasta atau lembaga lain yang setingkat dengan perguruan tinggi. Mahasiswa dinilai memiliki tingkat intelektualitas yang tinggi, kecerdasan dalam berpikir dan kerencanaan dalam 


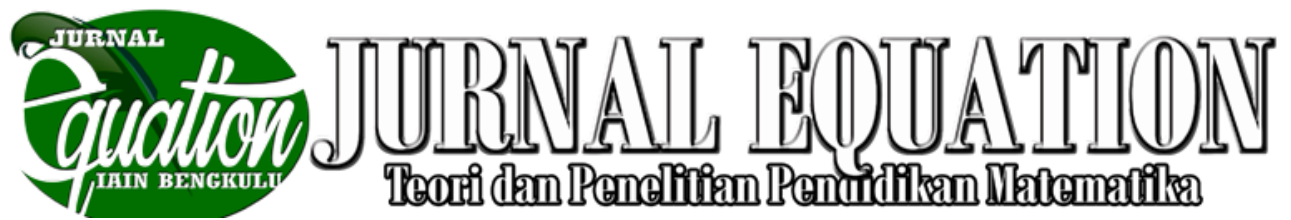

Volume 1 Nomor 2, September 2018, ISSN 2599-3291 (Cetak), ISSN 2614-3933 (Online)

bertindak. Berpikir kritis dan bertindak dengan cepat dan tepat merupakan sifat yang cenderung melekat pada diri setiap mahasiswa, yang merupakan prinsip yang saling melengkapi. Seorang mahasiswa dikategorikan pada tahap perkembangan yang usianya 18 sampai 25 tahun. Tahap ini dapat digolongkan pada 19 masa remaja akhir sampai masa dewasa awal dan dilihat dari segi perkembangan, tugas perkembangan pada usia mahasiswa ini ialah pemantapan pendirian hidup (Yusuf, 2012: 27). Berdasarkan uraian diatas dapat disimpulkan bahwa mahasiswa ialah seorang peserta didik berusia 18 sampai 25 tahun yang terdaftar dan menjalani pendidikannnya di perguruan tinggi baik dari akademik, politeknik, sekolah tinggi, institut dan universitas. Sedangkan dalam penelitian ini, subyek yang digunakan ialah dua mahasiswa yang berusia 23 tahun dan masih tercatat sebagai mahasiswa aktif.

\section{Karakteristik Perkembangan Mahasiswa}

Seperti halnya transisi dari sekolah dasar menuju sekolah menengah pertama yang melibatkan perubahan dan kemungkinan stres, begitu pula masa transisi dari sekolah menengah atas menuju universitas. Dalam banyak hal, terdapat perubahan yang sama dalam dua transisi itu. Transisi ini melibatkan gerakan menuju satu struktur sekolah yang

Epran

Respon Mahasiswa.... lebih besar dan tidak bersifat pribadi, seperti interaksi dengan kelompok sebaya dari daerah yang lebih beragam dan peningkatan perhatian pada prestasi dan penilaiannya (Santrock, 2002: 74) Perguruan tinggi dapat menjadi masa penemuan intelektual dan pertumbuhan kepribadian. Mahasiswa berubah saat merespon terhadap kurikulum yang menawarkan wawasan dan cara berpikir baru seperti; terhadap mahasiswa lain yang berbeda dalam soal pandangan dan nilai, terhadap kultur mahasiswa yang berbed 20 dan terhadap anggota fakultas yang memberikan model baru. Pilihan perguruan tinggi dapat mewakili pengejaran terhadap hasrat yang menggebu atau awal dari karir masa depan (Papalia dkk, 2008: 672 ) Ciri-ciri perkembangan remaja lanjut atau remaja akhir (usia 18 sampai 21 tahun) dapat dilihat dalam tugas-tugas perkembangan yaitu (Gunarsa: 2001: 129-131) : a) Menerima keadaan fisiknya; perubahan fisiologis dan organis yang sedemikian hebat pada tahuntahun sebelumnya, pada masa remaja akhir sudah lebih tenang. Struktur dan penampilan fisik sudah menetap dan harus diterima sebagaimana adanya. Kekecewaan karena kondisi fisik tertentu tidak lagi mengganggu dan sedikit demi sedikit mulai menerima keadaannya. b) Memperoleh kebebasan emosional; masa remaja akhir sedang pada masa proses melepaskan diri dari 


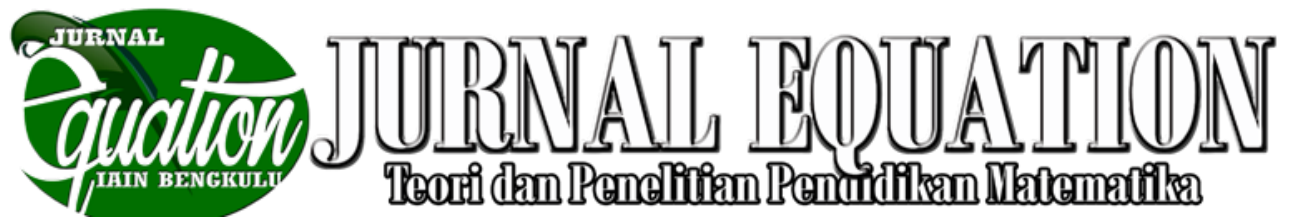

Volume 1 Nomor 2, September 2018, ISSN 2599-3291 (Cetak), ISSN 2614-3933 (Online)

ketergantungan secara emosional dari orang yang dekat dalam hidupnya (orangtua). Kehidupan emosi yang sebelumnya banyak mendominasi sikap dan tindakannya mulai terintegrasi dengan fungsi-fungsi lain sehingga lebih stabil dan lebih terkendali. Dia mampu mengungkapkan pendapat dan perasaannya dengan sikap yang sesuai dengan lingkungan dan kebebasan emosionalnya. c) Mampu bergaul; dia mulai mengembangkan kemampuan mengadakan hubungan sosial baik dengan teman sebaya maupun orang lain yang berbeda tingkat kematangan sosialnya. Dia mampu menyesuaikan dan memperlihatkan kemampuan bersosialisasi dalam tingkat kematangan sesuai dengan norma sosial yang ada. d) Menemukan model untuk identifikasi; dalam proses ke arah kematangan pribadi, tokoh identifikasi sering kali menjadi faktor penting, tanpa tokoh identifikasi timbul kekaburan akan model yang ingin ditiru dan memberikan pengarahan bagaimana bertingkah laku dan bersikap sebaik-baiknya. e) Mengetahui dan menerima kemampuan sendiri; pengertian dan penilaian yang objektif mengenai keadaan diri sendiri mulai terpupuk. Kekurangan dan kegagalan yang bersumber pada keadaan kemampuan tidak lagi mengganggu berfungsinya kepribadian dan menghambat prestasi yang ingin dicapai. f) Memperkuat penguasaan diri atas dasar skala nilai dan norma; nilai pribadi yang tadinya menjadi norma dalam melakukan sesuatu tindakan bergeser ke arah penyesuaian terhadap norma di luar dirinya. Baik yang berhubungan dengan nilai sosial ataupun nilai moral. Nilai pribadi adakalanya harus disesuaikan dengan nilai-nilai umum (positif) yang berlaku dilingkungannya. g) Meninggalkan reaksi dan cara penyesuaian kekanak-kanakan; dunia remaja mulai ditinggalkan dan dihadapannya terbentang dunia dewasa yang akan dimasuki. Ketergantungan secara psikis mulai ditinggalkan dan ia mampu mengurus dan menentukan sendiri. Dapat dikatakan masa ini ialah masa persiapan ke arah tahapan perkembangan berikutnya yakni masa dewasa muda. Apabila telah selesai masa remaja ini, masa selanjutnya ialah jenjang kedewasaan.

Pendidikan karakter sebenarnya sudah menjadi orientasi dalam sistem pendidikan kita. Hal ini terlihat pada pasal 3 UU RI Tahun 2003 tentang Sistem Pendidikan Nasional yang menyebutkan bahwa pendidikan nasional berfungsi untuk mengembangkan kemampuan dan membentuk watak serta peradaban bangsa yang bermartabat dalam rangka mencerdaskan kehidupan bangsa, bertujuan untuk berkembangnya potensi peserta didik agar menjadi manusia yang beriman dan bertakwa kepada Tuhan Yang 


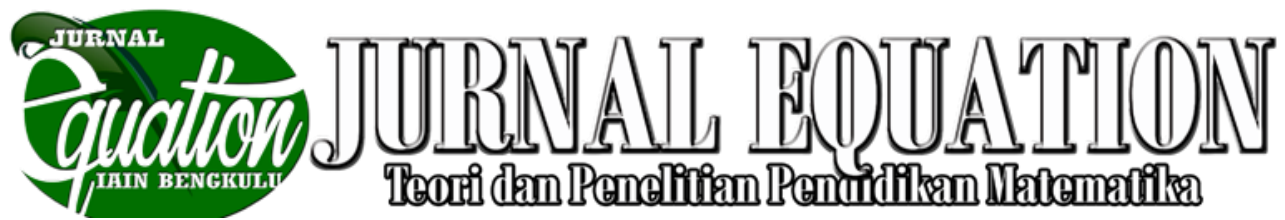

Volume 1 Nomor 2, September 2018, ISSN 2599-3291 (Cetak), ISSN 2614-3933 (Online)

Maha Esa, berakhlak mulia, sehat, berilmu, cakap, kreatif, mandiri, dan menjadi warga negara yang demokratis serta bertanggungjawab. Hal itu diperkuat dalam tujuan pendidikan di tingkat satuan pendidikan pada Peraturan Menteri Pendidikan Nasional Nomor 23 tahun 2006 tentang Standar Kompetensi Lulusan. Dalam peraturan itu, disebutkan bahwa tujuan pendidikan dasar adalah meletakkan dasar kecerdasan, pengetahuan, kepribadian, akhlak mulia, serta keterampilan hidup mandiri dan mengikuti pendidikan lanjut. Adapun tujuan pendidikan menengah adalah untuk meningkatkan kecerdasan, pengetahuan, kepribadian, akhlak mulia, serta keterampilan hidup mandiri dan mengikuti pendidikan lanjut. Sementara itu, tujuan pendidikan menengah kejuruan adalah untuk meningkatkan kecerdasan, pengetahuan, kepribadian, akhlak mulia, serta keterampilan hidup mandiri dan mengikuti pendidikan lanjut sesuai dengan kejuruannya. Dari tujuantujuan itu terlihat bahwa pada semua tingkat satuan pendidikan, peningkatan kepribadian, akhlak mulia, serta keterampilan hidup mandiri merupakan merupakan tujuan yang penting. Sementa.itu dalam peraturan Menteri Pendidikan Nasional Nomor 22 tahun 2006 tentang Standar Isi: Pendidikan dasar dan menengah disebutkan bahwa akhlak mulia mencakup etika, budi pekerti, atau moral sebagai perwujudan dari pendidikan agama. Dari rumusan itu, nampak bahwa secara implisit pendidikan karakter sudah menjadi arah dalam tujuan pendidikan kita.

\section{Pembelajaran Matematika}

Pembelajaran matematika bagi para siswa merupakan pembentukan pola pikir dalam pemahaman suatu pengertian maupun dalam penalaran suatu hubungan diantara pengertian-pengertian itu. Dalam pembelajaran matematika, para siswa dibiasakan untuk memperoleh pemahaman melalui pengalaman tentang sifat-sifat yang dimiliki dan yang tidak dimiliki dari sekumpulan objek (abstraksi). Siswa diberi pengalaman menggunakan matematika sebagai alat untuk memahami atau menyampaikan informasi misalnya melalui persamaan-persamaan, atau tabel-tabel dalam model-model matematika yang merupakan penyederhanaan dari soal-soal cerita atau soalsoal uraian matematika lainnya NCTM (National Coucil of Teachers of Mathematics)

(Depdiknas, 2006:346) menyebutkan pemberian mata pelajaran matematika bertujuan agar peserta didik memiliki kemampuan sebagai berikut.

a. Memahami konsep matematika, menjelaskan keterkaitan antara konsep dan mengaplikasi konsep 


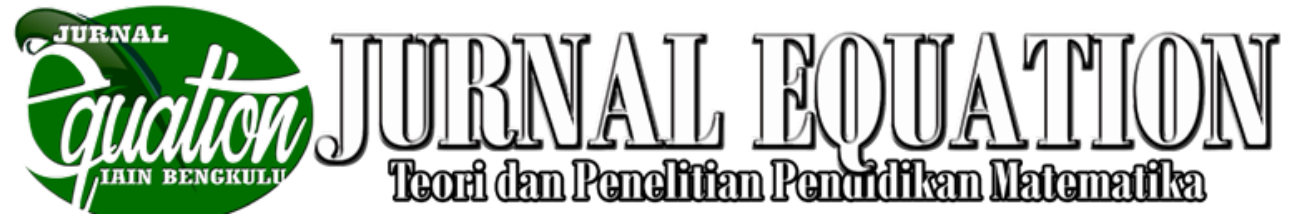

Volume 1 Nomor 2, September 2018, ISSN 2599-3291 (Cetak), ISSN 2614-3933 (Online)

atau logaritma secara luwes, akurat, efisien dan tepat dalam pemecahan masalah.

b. Menggunakan penalaran pada pola dan sifat, melakukan manipulasi matematika dalam membuat generalisasi, menyusun bukti, atau menjelaskan gagasan dan pernyataan matematika.

c. Memecahkan masalah yang meliputi kemampuan memahami masalah, merancang model matematika, menyelesaikan model, dan menafsirkan solusi yang diperoleh.

d. Mengkomunikasikan gagasan dengan simbol, tabel, diagram, atau media lain untuk menjelaskan keadaan/masalah.

e. Memiliki sifat menghargai kegunaan matematika dalam kehidupan, yaitu: memiliki rasa ingin tahu, perhatian, dan minat dalam pelajaran matematika serta sikap ulet dan percaya diri dalam pemecahan masalah. Tujuan umum pertama, pembelajaran matematika pada jenjang pendidikan dasar dan menengah adalah memberikan penekanan pada penataan latar dan pembentukan sikap siswa. Tujuan umum adalah memberikan penekanan pada keterampilan dalam penerapan matematika, baik dalam kehidupan sehari-hari maupun dalam membantu mempelajari ilmu pengetahuan lainnya.

Fungsi mata pelajaran matematika sebagai: alat, pola pikir, dan ilmu atau pengetahuan (Erman Suherman, 2003:56). Pembelajaran matematika di sekolah menjadikan guru sadar akan perannya sebagai motivator dan pembimbing siswa dalam pembelajaran matematika di sekolah.

Dengan memadukan uraian materi matematika (baik itu objek langsung atau objek tak langsung), pemilihan model, metode, atau pembelajaran yang tepat, yang sesuai dengan nilai karakter yang akan dikembangkan, serta melaksanakan pembelajaran matematika sesuai dengan saran dari Lickona tersebut, maka pendidikan karakter akan bisa terlaksana dalam proses pembelajaran matematika. Berapa karakater yang baik, yang belum bisa tertuang dalam proses pembelajaran matematika secara langsung, seperti: berpandangan jauh/luas, terus terang, berambisi, terhindar dari obat terlarang dan gaya hidup bebas, dan komitmen terhadap keluarga dapat disisipkan dalam pelaksanaan pembelajaran matematika di kelas, ketika mengahadapi situasi real yang terjadi di kelas, misalnya: guru/dosen terlambat karena ada keperluan keluarga seperti: mendadak mengantarkan ke rumah 


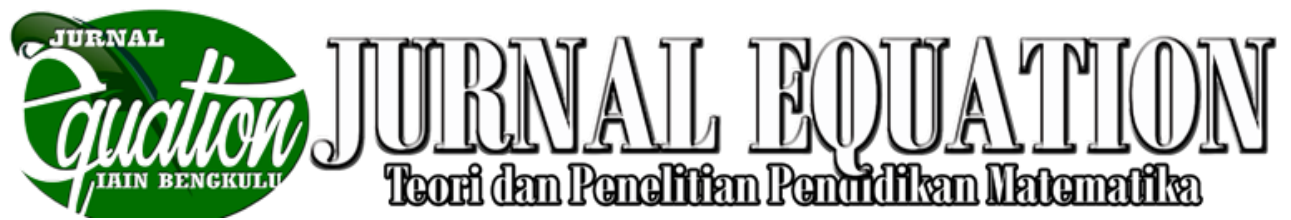

Volume 1 Nomor 2, September 2018, ISSN 2599-3291 (Cetak), ISSN 2614-3933 (Online)

sakit; melayat tetangga yang meninggal karena korban obat terlarang, membantu tetangga karena menjadi korban/keluarga yang broken home karena gaya hidup bebas, dan sebagainya.

\section{Matematika dan Pendidikan Karakter}

Secara material objek matematika dapat berupa benda-benda konkret, gambar atau model kubus, berwarna-warni lambang bilangan besar atau kecil, kolam berbentuk persegi, atap rumah berbentuk limas, piramida-piramida di Mesir, kuda-kuda atap rumah berbentuk segitiga siku-siku, roda berbentuk lingkaran, dan seterusnya. Secara material objek matematika itu berada di lingkungan atau sekitar kita. Secara formal objek matematika berupa benda-benda pikir. Benda-benda pikir diperoleh dari benda konkret dengan melakukan abstraksi dan idealisasi. Abstraksi adalah kegiatan yang hanya mengambil sifat-sifat tertentu saja untuk dipikirkan atau dipelajari. Idealisasi adalah kegiatan yang menganggap sempurna sifat-sifat yang ada. Dari model kubus yang terbuat dari kayu jati, dengan abstraksi kita hanya mempelajari bentuk dan ukuran saja. Dengan idealisasi kita memperoleh informasi bahwa ruas-ruas kubus berupa garis lurus yang betul-betul lurus tanpa cacat. Secara normatif, objek-objek matematika berupa makna yang terkandung di dalam objek-objek material dan formal. Makna-makna yang terungkap dari matematika material dan matematika formal itulah kemudian yang menghasilkan value atau nilai matematika. Misalnya, objek matematika material berupa "bilangan 2 yang terbuat dari papan triplek yang digergaji dan kemudian diberi warna yang indah". Di dalam khasanah matematika material, kita dapat memikirkan bilangan 2 yang lebih besar, bilangan 2 yang lebih kecil, bilangan 2 yang berwarna merah, bilangan 2 yang berwarna biru, dan seterusnya. Pada dimensi formal terdapat pencampuradukan antara pengertian bilangan dan angka. Tetapi, begitu kita memasuki dimensi matematika formal, semua sifat dari bilangan 2 tadi kita singkirkan, dan yang kita pikirkan sifat nilainya saja dari 2. Kita tidak mampu memikirkan nilai bilangan 2 jika kita tidak memiliki bilangan-bilangan yang lain. Nilai bilangan 2 adalah lebih besar dari bilangan 1 , tetapi lebih kecil dari bilangan 3. Secara normatif, makna bilangan 2 mengalami ekstensi dan intensi. Jika diintensifkan, bilangan 2 dapat bermakna "genap", dapat bermakna "pasangan", dapat bermakna "bukan ganjil", dapat bermakna "ayah dan ibu", atau dapat bermakna "bukan satu". Secara metafisik, bilangan 2 dapat bermakna "jarak antara dua hal" misalnya jarak antara potensi dan vitalitas, jarak antara konkret dan abstrak, jarak antara subjek dan objek, dan seterusnya. Jika diekstensifkan, 


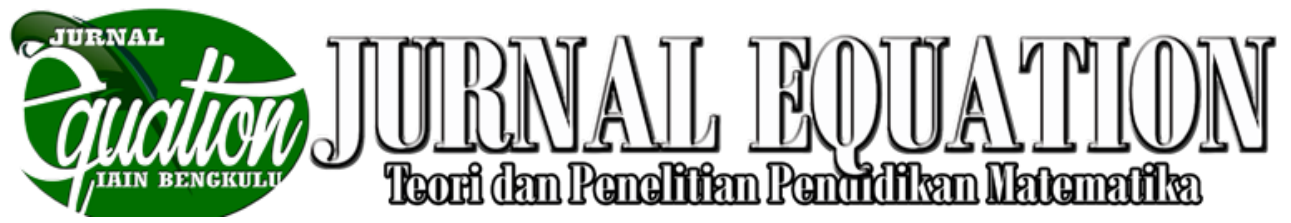

Volume 1 Nomor 2, September 2018, ISSN 2599-3291 (Cetak), ISSN 2614-3933 (Online)

maka makna bilangan 2 dapat berupa 2 teori, 2 teorema, 2 sistem matematika, 2 variabel, 2 sistem persamaan, dan seterusnya. Dengan cara yang sama kita dapat melakukan intensi dan ekstensi untuk semua objek matematika. Uraian di atas barulah tentang dimensi matematika dari bilangan 2 dan objek-objek matematika yang lainnya. Jika ingin menguraikan bagaimanakah implementasi pendidikan karakter dalam pendidikan matematika di sekolah, kita masih harus memikirkan pendidikan matematika, pembelajaran matematika, berpikir matematika, dan seterusnya. Katagiri (2004) menguraikan bahwa berpikir matematika meliputi 3 aspek: pertama, sikap matematika, kedua, metode memikirkan matematika, dan ketiga, konten matematika. Berpikir matematika juga merentang berpikir matematika pada dimensinya. Artinya, ada berpikir matematika di tingkat sekolah/material, atau perguruan tinggi/formal.

Secara umum, sikap matematika ditunjukkan oleh indikator adanya rasa senang dan ikhlas untuk mempelajari matematika, sikap yang mendukung untuk mempelajari matematika, pengetahuan yang cukup untuk mempelajari matematika, rasa ingin tahu, kemauan untuk bertanya, untuk memperoleh keterampilan dan pengalaman matematika. Secara pragmatis, kita dapat menyatakan bahwa matematika adalah himpunan dari nilai kebenaran yang terdiri dari teorema-teorema beserta bukti-buktinya. Sementara itu, filsafat matematika muncul ketika kita meminta pertanggungjawaban akan kebenaran matematika. Oleh karena itu, filsafat matematika merupakan pandangan yang memberikan gambaran penting dan menerangkan secara tepat bagaimanakah seseorang dapat mengerjakan matematika. Perbedaan filsafat matematika yang dianut akan menyebabkan perbedaan praktik dan hasil pendidikan matematika. Implementasi pendidikan karakter dalam pendidikan matematika merupakan implikasi dari kesadaran akan pentingnya refleksi kegiatan matematika melalui kajian matematika dan pendidikan matematika pada berbagai dimensinya. Dengan demikian implementasi pendidikan karakter dalam pendidikan matematika mengandung makna seberapa jauh kita mampu melakukan kegiatan dalam rentang niat, sikap, pengetahuan, keterampilan dan pengalaman matematika, pendidikan matematika, dan pembelajaran matematika. Implementasi pendidikan karakter dalam pendidikan matematika dapat dicapai atas dasar pemahaman tentang pengetahuan matematika yang bersifat objektif dan pelaku matematika yang bersifat subjektif di dalam usahanya untuk memperoleh justifikasi 


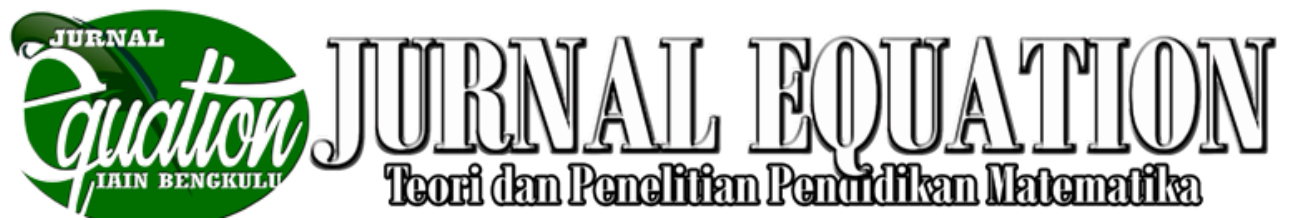

Volume 1 Nomor 2, September 2018, ISSN 2599-3291 (Cetak), ISSN 2614-3933 (Online)

tentang kebenaran matematika melalui kreasi, formulasi, representasi, publikasi dan interaksi. Secara eksplisit implementasi pendidikan karakter dalam pendidikan matematika mendasarkan pada : (1) pengetahuan matematika pada berbagai dimensinya, yang meliputi hakikat, pembenaran, dan kejadiannya, (2) objek matematika pada berbagai dimensinya yang meliputi hakikat dan asal-usulnya, (3) penggunaan matematika formal yang meliputi efektivitasnya dalam sains, teknologi, dan ilmu lainnya, serta (4) praktik matematika pada berbagai dimensi secara lebih umum termasuk aktivitas para matematikawan atau aktivitas matematika para siswa SD.

\section{METODE PENULISAN}

Dalam melakukan penelitian ilmiah harus dilakukan teknik penyusunan yang sistematis untuk memudahkan langkah-langkah yang akan diambil. Begitu pula yang dilakukan penulis dalam penelitian ini, langkah pertama yaitu dengan melakukan studi literatur pada buku-buku yang membahas tentang Pembelajaran Matematika dan Pendidikan Karakter, jurnal, dan penelitian yang telah dilakukan yang berkaitan dengan Pembelajaran Matematika dan Pendidikan Karakter.

\section{HASIL DAN PEMBAHASAN}

Proses Pengimplementasian Nilai Karakter Dalam Pembelajaran Matematika

Menurut hasil penelitian naskah publikasi yang dilakukan Oleh Chyndhy Indra Masandhy (2015), proses pembelajaran ini saling berkaitan antara tahapan satu dengan yang lainya, yang didalamnya terdapat implimentasi nilai-nilai karakter yang saling berkesinambungan. Tahapan-tahapanya adalah sebagai berikut:

1. Mengucapkan salam dan doa sebelum dan sesudah pembelajaran.

Salam dan doa merupakan merupakan satu kesatuan akan tetapi dapat berdiri sendiri, karena didalam salam terdapat doa, kebaikan untuk memuliakan manusia yang diberi salam. Sedangkan didalam doa terdapat harapan, keinginan dari manusia agar dapat diwujudkan oleh Alloh SWT.

2. Memberi semangat kepada mahasiswa.

Salah satu hal yang paling membangkitkan semangat adalah motivasi. Motivasi merupakan hal yang diperlukan untuk membangkitkan kesadaran mahasiswa tentang arti pentingnya belajar. Motivasi juga dapat membangkitkan tentang arti pentingnya mengembangkan karakter 


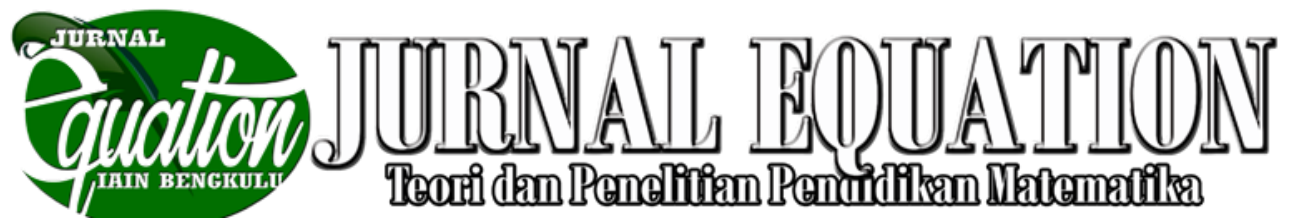

Volume 1 Nomor 2, September 2018, ISSN 2599-3291 (Cetak), ISSN 2614-3933 (Online)

dalam diri mahasiswa. Hal ini didukung oleh penelitian yang dilakukan Sri Winarni (2013) yang berjudul "Integrasi Pendidikan Karakter Dalam Perkuliahan". Beliau menyebutkan bahwa dalam hal tujuan, kegiatan belajar yang menanamkan nilai adalah apabila tujuan kegiatan tersebut tidak hanya berorientasi pada pengetahuan dan keterampilan, tetapi juga sikap atau karakter.

3. Menanamkan sikap religius, jujur, toleransi, disiplin, kerja keras, kreatif, demokratis, rasa ingin tahu dalam pembelajaran.

Religius merupakan sikap dan perilaku yang patuh dalam melaksanakan ajaran agama yang dianutnya (Islam). Menanamkan sikap jujur dan disiplin kepada mahasiswa merupakan implementasi nilai-nilai karakter dalam pembelajaran matematika yang mengintegrasikan nilai keislaman. Menanamkan sikap toleransi juga merupakan bagian dari implementasi nilai-nilai karakter dalam pembelajaran matematika yang mengintegrasikan nilai keislaman. Hal ini disebabkan karena mahasiswa yang satu dan yang lain saling keterkaitan antara satu dengan yang lain. Dengan sikap toleransi yang berjalan dengan sebagaimana mestinya, pola pikir mahasiswa yang satu dengan yang lain akan saling padu. Menanamkan sikap kreatif dan bekerja keras ke mahasiswa juga merupakan bagian dari implementasi nilai-nilai keislaman dalam pembelajaran matematika yang mengintegrasikan nilai keislaman. Hal ini diterapkan untuk melatih kesabaran mahasiswa dalam mengerjakan soal-soal yang sulit. Menanamkan sikap demokratis dan rasa ingin tahu ke mahasiswa.

Dengan ini membuktikan bahwa satu aspek nilai karakter yang satu dengan yang lain memiliki satu keterikatan dengan nilai karakter yang lain. Hal ini didukung dengan penelitian yang dilakukan oleh Yenni Suzana, (2013) yang berjudul, "Pengembangan Nilai-Nilai Karakter Mahasiswa Dalam Pembelajaran Melalui Metode blended Learning." Dalam penelitiannya, beliau menjelaskan Indonesia dikenal sebagai bangsa yang beradab, bangsa yang berbudaya bangsa yang beretika, dan bangsa yang religius, itulah yang dikatakan sebagai 


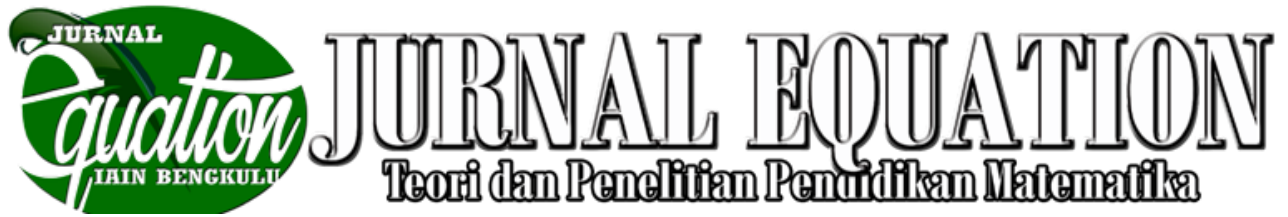

Volume 1 Nomor 2, September 2018, ISSN 2599-3291 (Cetak), ISSN 2614-3933 (Online)

karakter bangsa Indonesia. Ini berarti bahwa seorang warga Indonesia dianggap memilki karakter bangsa jika dalam kehidupan sehari hari selalu mengimplementasikan nilai moralitas, regiusitas dan nilai-nilai luhur lainnya.

4. Keteladanan

Seorang mahasiswa ketika dalam pembelajaran tidak hanya semata-mata hanya ilmu yang diajarkan tanpa aplikasi. mahasiswa harus menjadi teladan yang baik bagi mahasiswa yang lain, memberikan contoh, agar mereka dapat melihat sesuatu yang baik untuk menjadi panutan.

\section{Perilaku Mahasiswa Sebagai Indikator}

Pencapaian Tujuan Implementasi Nilai-nilai

\section{Karakter}

Berdasarkan observasi langsung dan wawancara, maka diperoleh hasil penelitian sebagai berikut: 1) mahasiswa memenuhi indikator pencapain nilai karakter jujur, 2) mahasiswa memenuhi indikator pencapain nilai karakter disiplin 3) mahasiswa memenuhi indikator pencapain dari nilai karakter kerja keras, 4) mahasiswa memenuhi indikator pencapain nilai karakter kreatif, 5) mahasiswa memenuhi indikator pencapain nilai karakter mandiri, 5) mahasiswa memenuhi indikator pencapain dari nilai karakter rasa ingin tahu 6) mahasiswa memenuhi indikator pencapain dari nilai karakter bersahabat dan komunikatif dan 7) mahasiswa memenuhi indikator pencapain dari nilai karakter tanggung jawab.

Berdasarkan hasil penelitian, maka dapat dirumuskan bahwa mahasiswa mengalami perubahan karakter dan perilaku setelah mengikuti pembelajaran matematika, yakni mahasiswa semakin jujur, disiplin, kerja keras, kreatif, mandiri, rasa ingin tahu, bersahabat dan komunikatif, serta tanggungjawab. Mengacu hasil pembelajaran berupa perubahan karakter dan perilaku tersebut, maka nilai-nilai karakter memang dapat diimplementasikan dalam pembelajaran matematika kaitannya dengan tujuan menumbuh kembangkan nilai-nilai karakter dalam diri mahasiswa sesuai dengan indikator-indikator pencapaian yang telah ditentukan. Lebih lanjut, indikator yang menunjukkan nilai-nilai karakter telah diimplementasikan dalam pembelajaran matematika tidak lagi didasarkan pada hasil belajar mahasiswa yang dilaporkan secara tertulis dalam rapor, akan tetapi lebih kepada perubahan karakter dan perilaku mahasiswa yang cenderung ke arah yang lebih baik setelah mengikuti pembelajaran yang bersangkutan. Walaupun indikator ini tidak dapat dilaporkan secara tertulis, namun tata perilaku mahasiswa dalam keseharian sudah 


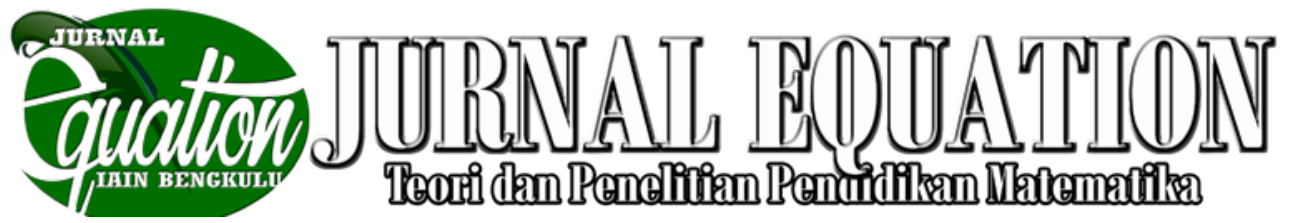

Volume 1 Nomor 2, September 2018, ISSN 2599-3291 (Cetak), ISSN 2614-3933 (Online)

cukup menunjukkan bahwa nilai-nilai karakter telah diimplementasikan dalam pembelajaran matematika secara tepat sesuai pedoman pembelajaran. Hasil penelitian tersebut didukung penelitian Ikhwanudin (2010) yang menyatakan bahwa implementasi nilai-nilai karakter kerja keras dan kerjasama mampu meningkatkan skill dan prestasi belajar mahasiswa. Hal senada juga diutarakan Hasanah (2013) dalam penelitiannya yang menyatakan bahwa nilai-nilai karakter berupa jujur, cerdas, peduli, dan tangguh merupakan nilai-nilai inti yang menjadi dasar dalam kaitannya dengan implementasi nilai-nilai karakter di perguruan tinggi. Berdasarkan relevansi tersebut, disimpulkan bahwa agar hasil belajar berupa perubahan karakter dan perilaku mahasiswa ke arah yang lebih baik dapat tercapai secara riil maka implementasi nilai-nilai karakter harus benar-benar dilaksanakan sesuai dengan pedoman pembelajaran.

\section{PENUTUP}

Berdasarkan tinjauan pustaka dan pembahasan yang diperoleh, dapat disimpulkan beberapa hal yaitu nilai-nilai karakter dalam pembelajaran matematika meliputi aspek adanya rasa senang dan ikhlas untuk mempelajari matematika, sikap yang mendukung untuk mempelajari matematika, pengetahuan yang cukup untuk mempelajari matematika, rasa ingin tahu, kemamuan untuk bertanya, untuk memperoleh keterampilan dan pengalaman matematika serta keteladanan. Aspek selanjutnya religius, toleransi, jujur, disiplin, kerja keras, kreatif, demokratis.

\section{DAFTAR PUSTAKA}

Masandhy, Chyndhy Indra. 2015. Respons Mahasiswa Terhadap Pengembangan Nilai-Nilai Karakter Setelah Mengimplementasikan Pembelajaran Matematika Yang Mengintegrasikan Nilai-Nilai Islam. Naskah Publikasi. Universitas Muhammadiyah Surakarta. Isworo, 2017.

https://isosuwarso.wordpress.com/2017 /06/18/pendidikan-karakter-yangberhubungan-dengan-pembelajaranmatematika/ (Diakses: 08-02-2019). Depdiknas. 2006. Kurikulum Tingkat Satuan Pendidikan (KTSP). Jakarta: Departemen Pendidikan Nasional. Winarni, Sri. 2013. "Integrasi Pendidikan Karakter Dalam Perkuliahan."(Jurnal Pendidikan Karakter Tahun III Nomor 1) Yogyakarta: FIK Universitas Negeri Yogyakarta.

Amir, Syafruddin. 2013. "Pancasila As Integration Philosophy of Education And National Character". International Journal of Scientific \& Technology 


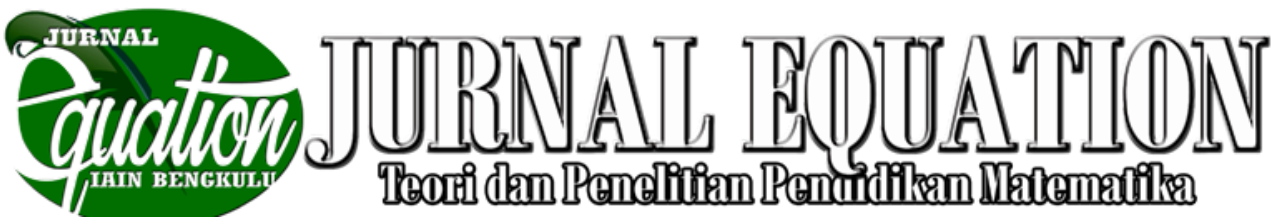

Volume 1 Nomor 2, September 2018, ISSN 2599-3291 (Cetak), ISSN 2614-3933 (Online)

Research Volume 2, Issue 1, January 2013, pp. 54-57.

Prabowo, Agung., \& Sidi, Pramono. 2010.

"Memahat Karakter Melalui

Pembelajaran Matematika". Proceedings of The 4th International Conference on Teacher Education; Join Conference UPI \& UPSI Bandung, Indonesia, 8-10 November 2010, pp. 165-177. 